This item was submitted to Loughborough's Research Repository by the author.

Items in Figshare are protected by copyright, with all rights reserved, unless otherwise indicated.

\title{
Buy now - pay later. Credit: the mainstay of the retail furniture business?
}

PLEASE CITE THE PUBLISHED VERSION

http://www.ashgate.com/isbn/9780754650461

PUBLISHER

(C) Ashgate

VERSION

AM (Accepted Manuscript)

LICENCE

CC BY-NC-ND 4.0

REPOSITORY RECORD

Edwards, Clive. 2019. "Buy Now - Pay Later. Credit: The Mainstay of the Retail Furniture Business?". figshare. https://hdl.handle.net/2134/9477. 
This item was submitted to Loughborough's Institutional Repository (https://dspace.lboro.ac.uk/) by the author and is made available under the following Creative Commons Licence conditions.

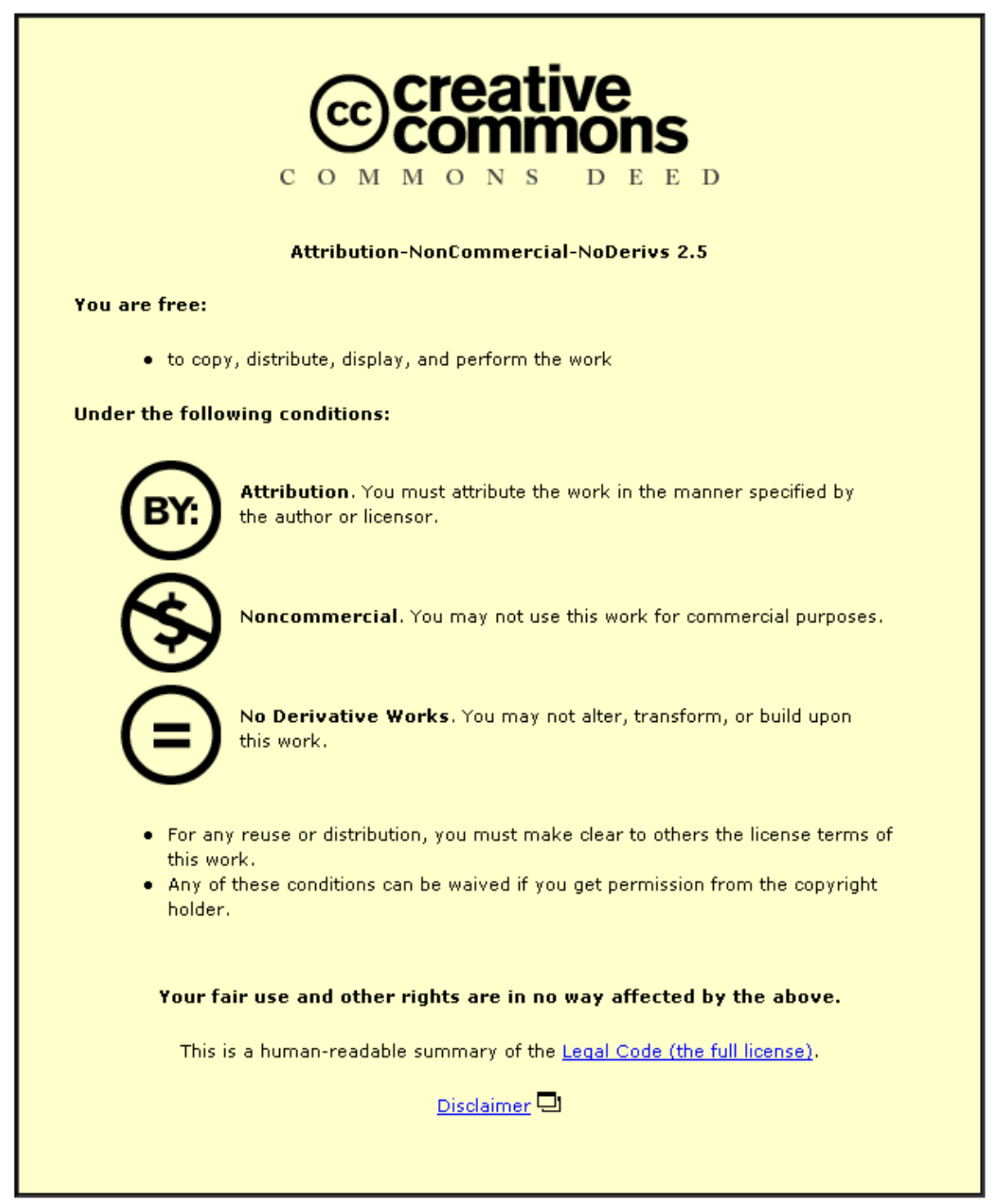

For the full text of this licence, please go to: http://creativecommons.org/licenses/by-nc-nd/2.5/ 
Clive Edwards

\section{Buy Now - Pay Later. Credit: the mainstay of the retail furniture business? Introduction}

This chapter focuses on the role of credit in relation both to the furniture retailer and the consumer, with particular emphasis on the period 1850-1980. It was during this time that the retail furniture business expanded to meet the growing demands and purchasing power of the British population. The majority of the study relates to domestic furniture, but in many cases, the commentary considers attitudes applicable also to other durable commodities.

One of the intentions of this chapter is to explore the important role played by credit (and in particular instalment credit) in the changes that have occurred in the culture and practice of retailing and consumption. Savitt for example points to the need for historians to map changes in distribution systems, as not only the chronicling of famous names or locations, but also as a series of interactions between social, economic, and geographic factors. ${ }^{1}$ This work is an attempt to examine one aspect of these interactions, namely credit. The importance of its role for consumers has been emphasised by Finn, who forcefully claims that 'the expansion of consumption in modern England was powered in significant part by personal credit relations. ${ }^{2}$

This chapter will also consider the nature of credit in relation to consumer needs and demands. A truly consumerist society 'involves large numbers of people staking a real portion of their personal identities and their quest for meaning - even their emotional satisfaction - on the search for and acquisition of goods' ${ }^{3}$ The availability of credit was one tool in creating this sort of society. Indeed, societies 'in which choice and credit are readily available, in which social value is defined in terms of purchasing power and material possessions, and in which there is a desire, above all, for that which is new modern exciting and fashionable', ${ }^{4}$ are the foundation of modern

${ }^{1}$ R. Savitt, 'Looking back to see ahead: writing the history of American retailing', Journal of Retailing, 65, 3, 1989, 326-55.

${ }^{2}$ M. Finn, The Character of Credit: Personal Debt in English Culture, 1740-1914, (Cambridge, 2003), 17.

${ }^{3}$ P.N. Stearns, 'Stages of consumerism: recent work on the issues of periodization', Journal of Modern History, 69, 1997, 105.

${ }^{4}$ J. Benson, The Rise of Consumer Society in Britain 1880-1980 (London, 1994), 4. 
retailing and consumption practices. This connection between the business and the culture of consumption is important in understanding the key role of credit in the consumption of home furnishings.

It is essential to recognise that credit was, in the main, beneficial to both retailers and consumers, and that both had a rationale for using it. However, retailers who offer credit terms have often been accused of selling credit - with less emphasis on the goods - and have been represented as 'sharks' and money-lenders, operating dubious trading practices. ${ }^{5}$ Although financial malpractice clearly affected many consumers, the use of credit facilities became normal business practice in the early modern period, and by the middle of the nineteenth century the spread of credit gradually enabled a growing proportion of consumers to begin to purchase durable goods out of income, and thus join the 'consumer society'. 6

Against this backdrop, the relationship between credit facilities and consumption practices, and their impact on customers and retailers will be examined. The picture revealed is much more complex than it may at first appear. From book debts to weekly collections at the door, from credit sales and hire-purchase to post-dated cheques and credit cards, the chapter will explore the range of credit made available to customers. It will also consider the extent to which credit was one of the key factors for a successful retail furniture business.

[Credit has been a tool of business for many centuries in a wide range of trades, and has had a variety of roles to play. In some cases, it has been associated with a highclass trade, where accounts were made up after the often bespoke goods had been supplied. In other cases, credit has been stigmatised, and denigrated in favour of saving-up and making cash purchases. ${ }^{7}$ As Bill Lancaster suggests, the 'tension

\footnotetext{
${ }^{5}$ See for example the cases quoted in P. Scott, 'The twilight world of interwar British hire purchase', Past and Present, 177, 2002, 196-225.

${ }^{6}$ For more on the central role of consumer credit in the period 1740-1914, see Finn, The Character of Credit.

${ }^{7}$ See R. Gelpi and F. Julien-Labruyere, The History of Consumer Credit, Doctrines and Practice (London, 2000); L. Calder, Financing the American Dream: A History of Consumer Credit (Princeton, 1999); N. Cox, The Complete Tradesman: A Study of Retailing, 1550-1820 (Aldershot, 2000), especially chapter 5. See also the Cooperative movement's attitude, discussed below.
} 
between hedonism and self-restraint is usually expressed in condemnatory remarks by elite observers on the consuming patterns of lower or newer social groups. ${ }^{8}$ In the case of furniture, like other expensive items such as sewing machines, pianos, and more recently, motorcars, credit has often been the only way that retailers could sell their stocks and many consumers (not just the working class, could furnish and equip their homes. Retailers were likely to expand their business if they offered credit, in many cases mining a seam of customers who would not have purchased in any other way. The problem was, and still is, that credit, like all aspects of retailing, raises differing issues for the two parties involved. From a retailer's point of view, there were policy matters of funding the purchase of stocks before full payment had been made, the expenses involved in offering and controlling credit systems, concern for the image of the store, and the probability of bad debts.

From the consumer's point of view, credit purchase was also a double-edged sword. On the one hand, the opportunity of 'buying now and paying later', which gave the ability to acquire high-price goods by way of staggered payments, was often the only way many consumers could enter the market for new goods. On the other hand, excessive interest rates, the potential in some cases for the 'snatch back' of the goods, and the wider morality issue of 'going into debt', were restraining factors.

Indeed, although social reformers had been raising these issues for many years prior to the major legislation relating to hire-purchase in 1938, consumer protection from the excesses of some retailers was slow in coming. By the mid twentieth century, however, the British government had not only legislated against many of the abuses of hire-purchase, but had also begun to use controls on credit as an economic tool. Despite continued reservations, for example about the level of personal indebtedness, it is nevertheless clear that the ubiquity of credit in the later twentieth century and twenty-first century demonstrates its ultimately widespread acceptance. ]

\section{Precursors of the mainstream}

Although credit had been part of the retail infrastructure since at least the sixteenth century, ${ }^{9}$ in terms of furniture selling it was generally limited to high-class businesses and the sale of bespoke work, which had become firmly established by the eighteenth century. The furnishing trades of the eighteenth century were sophisticated in their

\footnotetext{
${ }^{8}$ B. Lancaster, The Department Store: A Social History (Leicester, 1995), 162.

${ }^{9}$ Cox, The Complete Tradesman, 146.
} 
business dealings, despite or perhaps because of supplying a relatively small market. ${ }^{10}$ There were at least two forms of credit available. ${ }^{11}$ For the richer customers it was common for invoices to be submitted for major commissions on completion of the work. These invoices might take months or years to be paid, and it was not unusual for furnishers to be forced to vigorously chase their clients for payment of the debt. Secondly, an early form of instalment credit was available. For example, in 1707 Christopher Thornton of Southwark noted that 'you may also be furnished with chests of drawers, or looking glasses at any price, paying for them weekly as we shall agree'. ${ }^{12}$ In either case, one of the recurrent features of credit trading was the need to strike a balance between good and bad debts. In 1726, Daniel Defoe warned in his Complete English Tradesman that 'He that takes credit may give credit, but he must be exceedingly watchful, for it is the most dangerous state of life that a man can live in'. ${ }^{13}$ This matter is clearly exemplified by the case of a London upholsterer, a Mr Devenish, who had debts outstanding for over ten years, perhaps demonstrating a rather reckless attitude to the granting of credit. His executors recorded his list of debtors in 1802, and noted them as either (a) good, easy to collect, (b) repayable by instalments, (c) bad or irretrievable, or (d) they exceeded the Statute of Limitations. ${ }^{14}$ This range of debtors, from good to bad, or worse, represented the common gamut of credit risk for many businesses, large and small, which trod the thin line between

${ }^{10}$ For a brief introduction to furniture retailing in this period see D. Alexander, Retailing in England During the Industrial Revolution (London, 1970), 154-8. For a more detailed discussion on the retailing and consumption of eighteenth century furniture and furnishings, see C. Edwards, Turning Houses into Homes: A History of the Retailing and Consumption of Domestic Furnishings (Aldershot, 2004).

${ }^{11}$ Among smaller dealers, goods could also be exchanged to settle debts, payments could be made on account, and discounts could be granted for prompter payment. See Finn, The Character of Credit, especially 94-6.

${ }^{12}$ C. Thornton's Handbill quoted in A. Heal, The London Dictionary of Furniture Makers (London, 1953), 116.

13 D. Defoe, The Complete English Tradesman, quoted in Cox, The Complete Tradesman, 146.

${ }^{14}$ City of Westminster Archives, Letter Book of Thomas Devenish, 33 Villiers Street, London, March 1796 - June 1804, 36/36. 
meeting customers' demands, yet also remaining solvent and making a profit (or not in some cases).

\section{The expansion of retailing and credit}

The case of Mr Devenish showed that doing business with a small number of highly influential and exclusive customers who only settled their accounts annually (or even less frequently), as well as extending short-term credit to a wide range of customers, could have the effect of putting traders in a vulnerable position. Although the granting of credit was essential to acquiring the most prestigious commissions, some shopkeepers used the issue of the hidden costs of credit as a selling point for promoting cash sales. One example of a furniture retailer who faced this challenge directly was George Oakley of 8, Old Bond Street, London. His trade card (c. 180914) stated that 'The number of artists and mechanics as well as the large capital necessarily employed in this concern, together with the extensive stock kept for ye accommodation of the public are obvious reasons which render it impossible to conduct it by giving credit. The lowest price is therefore annex'd to every article for ready money or good bills'. ${ }^{15}$

Thus, one of the major distinctions that appeared to develop in the nineteenth century was between those outlets providing credit and those - apparently - trading for cash only. Although an exclusive and elite business continued to exist, a growing middleclass market was being exhorted to look upon careful money management as a necessary skill; buying for cash and not becoming indebted was one aspect of this. ${ }^{16}$ [cut endnote 16?] Nevertheless, as Finn has pointed out, cash and credit 'featured not as polar opposites ... but rather as unstable positions on the kaleidoscope spectrum of exchange mechanism available to the modern English consumer. ${ }^{17}$ Therefore, although it would have been easier to operate exclusively either a cash or a credit business, in reality many retailers offered both systems.

For retailers supplying privileged customers, the problems of debt collection that had plagued eighteenth century furniture dealers were still evident in the nineteenth. For example, the letter books of the London furnishers Miles and Edwards (c. late 1830s)

\footnotetext{
${ }^{15}$ British Museum, Department of Prints and Drawings, Banks Collection of Trade Cards, D.E. 627.

${ }^{16}$ See further below on the morality of credit.

${ }^{17}$ Finn, The Character of Credit, 284.
} 
demonstrate some of the pitfalls arising from abuses of goodwill. One example showed that the Duke of Sussex, who owed £1200, was only prepared to pay in instalments, whilst the Duke of Newcastle, who had a three year old debt of £59 16s $4 d$, only paid up when the partners began to charge interest. In another case the partners settled for a payment of $2 \mathrm{~s} 6 \mathrm{~d}$ in the pound. ${ }^{18}$

Benson and Shaw have noted the changing attitude to credit, especially in the drapery business, which were cited in evidence to a Government committee in 1833: 'the limitation of credit given by the retail trade [was] one part of the improved system of business'. ${ }^{19}$ More in general, many retailers emphasised that this limitation of credit was a means of keeping prices lower. In October 1831, for example, the drapers Jolly and Sons of Bath advertised their new shop in the Bath Chronicle, and emphasised that

[Economy] can only be obtained by an exclusive Ready Money System, no article being delivered unless upon prompt payment. The advantages of this system are great. By it the tradesman is enabled to purchase on the very best terms and from the quickness of his return, and his not incurring any risk of loss from bad debts a very small profit will remunerate him: the benefit thus arising to the consumer can only be judged by comparison. $^{20}$

Fifty years later, the London furnishing firm of Oetzmann and Co. considered, like Jolly and Sons, that although cash payment before or on delivery was sold as the most favourable system for the customer, it was the most favourable for the firm!. This, they suggested, was because 'any other method of payment, however short may be the credit given, entails an expensive system of book-keeping, a staff of clerks, collectors, inquiry agents and unfortunately too often the expense of solicitors and a loss by bad debts'. The cash system avoided these costs. ${ }^{21}$ Department stores, in particular,

\footnotetext{
${ }^{18}$ F. Mallett, 'Miles and Edwards of London', Furniture History, 6, 1970, 75.

${ }^{19}$ British Parliamentary Papers, 1833, Q. 1389, quoted in J. Benson and G. Shaw, The Evolution of Retail Systems 1800-1914 (Leicester, 1992), 32.

${ }^{20}$ Quoted in M. Moss and A. Turton, A Legend in Retailing: House of Fraser (London, 1989), 19.

${ }^{21}$ J. Oetzmann, Hints on House Furnishing and Decoration (London, n.d., c.1880), 294.
} 
offered lower prices for cash payment 'to extricate themselves from older trading practices that essentially protected wealthy shoppers at the storekeepers' expense' ${ }^{22}$ Department store customers were perceived to be people 'who 'pay as they go'. ${ }^{23}$

From the mid-nineteenth century, the increasing population, the growth in the number of households, and the growing desire for emulating the comforts of the 'middleclass' home, put mounting pressure on the systems of manufacturing, and, in turn, on the retailing of furniture. The change to regular wages that were paid weekly or fortnightly meant that many sections of the working classes were able to budget their finances and often for the first time, to buy durable goods for the home. As the supply side infrastructure changed to meet these new demands, credit became both a popular and a necessary part of many retailers' business strategy in an expanding market. ${ }^{24}$ Apart from 'simple' credit, whereby payment was delayed until the submission of an account, or until a certain quarter day, by the mid nineteenth century there was a move towards new contractual systems, including hire-purchase instalment plans. ${ }^{25}$ Although credit accounts remained part of the infrastructure of higher class retailing, it seems that it was the middle class that initially took advantage of instalment systems. For example, piano purchase on the 'three year system' was widespread by the 1860s, and ownership was an undoubted symbol of respectability. Peter Scott suggests that hire-purchase was 'originally confined to the more affluent sections of society, [but] it began to filter down to the working classes from the 1860s, when

\footnotetext{
${ }^{22}$ E. Rapport, Shopping for Pleasure: Women and the Making of London's West End (Princeton, 2000), 50.

${ }^{23}$ However, the practice was often different, as department stores soon introduced their own monthly accounts. The role of the department store in shaping consumer culture is discussed for example in R. Laermans, 'Learning to consume: early department stores and the shaping of modern consumer culture (1860-1914), Theory Culture and Society, 10, 1993, 79-102.

${ }^{24}$ For the developments in the production and supply of furniture, see C. Edwards, Victorian Furniture (Manchester, 1993).

${ }^{25}$ This change from 'status based' to 'contractually based' credit is discussed in Finn, The Character of Credit.
} 
Singer used the system to market its sewing machines'. ${ }^{26}$ [It is likely that some working-class consumers purchased sewing machines with the intention of supplementing their income, as well as for domestic use. The distinction between consumers who were granted credit on the basis of delayed payment of the full amount and those who were to pay small sums weekly seems to have been as much social as it was economic.

The ability of the working class to engage with the economy was aided by itinerant credit drapers. These travelling suppliers allowed working-class purchasers to buy textiles and furnishings for the home, in addition to clothing, on credit. ${ }^{27}$ For the rural [working-class the use of scotch drapers and itinerant traders, most of whom accepted payment in weekly instalments remained particularly important. The well-known writer Flora Thompson in Lark Rise to Candleford, recalled

A man who kept a small furniture shop [who] came round selling his wares on the instalment plan. On his first visit...he got no order at all; but on his second, one of the women, more daring than the rest, ordered a small wooden washstand and a zinc bath for washing day. Immediately washstands and zinc baths became the rage. None of the women could think how they had managed to exist without a washstand in their bedroom. $^{28}$

Shops introduced versions of the weekly system as well. One of a series of newspaper reports published in 1849, entitled Labour and the Poor in England and Wales, mentioned that 'When a young couple get married, they generally go to a furniture broker in Newcastle or Sunderland with perhaps $£ 10$ of ready money, obtaining a considerable part of their "plenishing" upon credit, and paying for it by

${ }^{26}$ Scott, 'The twilight world of interwar British hire purchase', 196. It should be borne in mind that in the second half of the nineteenth century many working class families furnished their homes from brokers and dealer in second-hand furniture.

${ }^{27}$ See M. Finn, 'Scotch Drapers and the politics of modernity: gender, class and national identity in the Victorian tally trade', in M. Daunton and M. Hilton, eds., The Politics of Consumption: Material Culture and Citizenship in Europe and America (Oxford, 2001), 89-108.

${ }^{28}$ F. Thompson, Lark Rise to Candleford (Harmondsworth, 1967, first published 1939), 125. 
instalments'. ${ }^{29}$ For this class of trade, it was not long before the credit terms seemed to become more important in the advertising matter than the goods themselves. In 1892, for example, the Crown Furnishing Company of Holloway, London, published a flyer emphasising its deposit and weekly terms. They advertised that they could furnish one room for $£ 5.00$ by payment of a 10 shillings deposit and 2 shillings a week thereafter. ${ }^{30}$ Other companies featured services that included free delivery, free life insurance and credit granted with no security required. There were two other developments, club and check trading, that offered credit to consumers. As the clubs were for saving towards a purchase often at a specific store, it is the check trading that is more relevant here. Both stores and independent financial institutions ran these check trading facilities. The Provident Clothing and Supply Company, for instance, was established in 1881, and soon developed links with furniture retailers as well as other types of suppliers. The customer used 'checks' supplied by the company to pay the retailer the normal price of the goods, and then paid back weekly amounts, including interest, to the check company. This arrangement was to the retailer's advantage, as the responsibility for the debt was removed and he / she obtained nearly full price for the goods (the check company taking a commission) without any involvement in the cost of granting credit or collecting payments.

The middle class could also take advantage of 'club' benefits. Indeed, one of the first specialist finance houses to fund credit sales was the Civil Service Mutual Furnishings Association, established in $1877 .{ }^{31}$ In 1890 John Robinson and James Syme set up the 'Robinson-Syme Ballot and Sale Furnishing Society', a credit supply operation. This club system of credit was described as follows: '[The] society has been formed to provide members of building societies and others, with the ordinary requisites for furnishing houses or apartments, and on such easy terms as cannot fail to make this undertaking ... a great success'. ${ }^{32}$ Using manufacturers, wholesalers, or other firms

29 J. Ginswick, ed., Labour and the Poor in England and Wales 1849-51, vol. ii (London, 1983), 40.

${ }^{30}$ National Art Library, London, Trade Catalogue Collection, Crown Furnishing Company estimate, 1892.

${ }^{31}$ quoted in Benson and Shaw, The Evolution of Retail Systems, 32.

${ }^{32}$ Robinson-Syme Furnishing Company, Rules of the' first' Robinson- Syme Ballot and Sale Furnishing Society Limited, (London, 1890), single sheet. 
on a published trading list, the customer could order goods and the supplier would be paid by the society, the member then paying back a fixed amount as agreed. As these 'club' schemes were limited in their membership, they indicate that credit for the middle classes, like mortgages, could be made acceptable if presented appropriately. However, the credit system that proved most popular was based on retailers who operated their own 'in-house' instalment payment systems, especially hire-purchase. Hire-purchase was apparently first promoted by the Countess of Blessington. In 1830 she had apparently been impressed by the Parisian furniture sellers' practice of hiring furniture by the quarter, half or whole year. The arrangement was that if after that period the furniture was purchased, the original sum agreed for the year's hire was to be allowed towards the purchase money. ${ }^{33}$ Apocryphal or not, the idea certainly took root as a tool for selling furniture and other high-priced items

A later example of the application of this form of credit to the retail furniture trade was the 'improved system of credit' adopted by the Surrey furniture merchant John Rawlings. In 1899 he explained that he offered a rental arrangement that could be converted to a later purchase, with an allowance for any rent paid. ${ }^{34}$ He commented that this 'hire-system' had first operated in the pianoforte trade and the benefits had been enormous, as 'there is scarcely a home [today] without its piano'. ${ }^{35}$ Rawlings explained why customers would benefit from his scheme: 'This system of credit renders the furniture on approval during the hiring and is the best guarantee that can be offered for soundness and efficiency of goods’ ${ }^{36}$

Although credit systems had potential pitfalls for both parties, hire-purchase transactions were particularly risky for customers who defaulted. In 1889, the bald dictionary definition of instalment sales or hire-purchase already hinted at some of the issues that reformers would soon be taking the trade to task for: 'A system adopted by some traders in substantial articles, such as furnitures, sewing machines, pianos etc., by which the seller retains the right of ownership until payment, and stipulates for the

\footnotetext{
${ }^{33}$ R. Harris and A. Sheldon, Hire-Purchase in a Free Society (London, 1961), 20-1.

34 J. Rawlings, Improved System of Credit (London, 1899).

${ }^{35}$ Ibid., 14.

${ }^{36}$ Ibid., 6.
} 
right to retake the article, without return of some or any part of what has already been paid, if the buyer makes default in any instalment. ${ }^{37}$

As the provision of credit for furniture purchases grew, there were to be many stories of unscrupulous dealers who benefited from the lack of legal protection for their customers. The law completely ignored the principle of equity between the parties in hire-purchase contracts. Instead, [it was judged that time was the essence of the contract, so any default in payment was a fundamental breach of contract. Although the law offered some redress to those suffering under the burden of 'normal' credit agreements made with oppressive creditors, it was to be some time before the anomalies with regard to hire-purchase were corrected. ${ }^{38}$

\section{The expansion of credit}

It was not long before some credit and hire-purchase systems acquired the bad name that they subsequently retained for much of the twentieth century. In particular, social and artistic reformers despised the commercial furnishers who apparently sold credit rather than style and design. In her 1897 book The Art of the House, for example, Rosamund Marriott Watson wrote that 'Some of the most illustrious writers of today inhabit homes and houses that, decoratively speaking are a slur upon civilisation.' The reason for this was to be found 'in the hire-purchase system and in Tottenham Court Road'. ${ }^{39}$ The apparent connection between bad design, credit, and that particular London thoroughfare would not have been lost on her middle-class readers, since the area was a well-known 'furniture' centre.

The provision of unconstrained credit was also criticised by social reformers, although this was as much a veiled critique of working-class consumption practices as it was of the financial system. As noted above, these criticisms often came from 'elite

\footnotetext{
${ }^{37}$ Century Dictionary, 1889, quoted in Calder, Financing the American Dream, 89.

38 There were some examples of hire purchase companies being involved in civil actions at this time. See the cases of Hire Purchase Furnishing Company v. Richens, 20 December 1887; French v. Tower Furnishing and Finance Company, 1 November 1888; Tower Furnishing and Finance Company v. Brown, 6 December 1889.

${ }^{39}$ Quoted in A. Adburgham, 'Give the customers what they want', Architectural Review, May 1977, 295.
} 
observers' who commented 'on the consuming patterns of lower or newer social groups'. ${ }^{40}$

Shaw Sparrow considered in his 1909 publication, Hints on House Furnishing, that 'thrift was looked upon as a foe to business: and we are now beginning to see that an over-stimulated demand in trade weakens the national character and begets an unrest of mind without will-power." 41 He devoted a whole chapter to the 'Systems or Methods of Furnishing.' His review began with a denunciation of the hire-purchase system. Readers were urged to buy only what they could afford outright, as well as to furnish according to their needs, not their wants. For Shaw Sparrow, the reasons were as much ethical as commercial: not only was it foolish to pay extra for the privilege of spreading payments, but he also suggested that 'purchase without payment dulls selfrespect. ${ }^{42}$ Shaw Sparrow was clearly writing for a middle-class audience that was probably more likely to be worried about the potential narrowing of class distinctions that easily-available credit offered, than they were about the ethics of credit. As goods were in part indicators of social standing and markers of distinction, it is not surprising that the potential growth in working-class consumption should raise some fears in middle-class groups.

Despite these critical voices, demand for goods grew rapidly as credit became socially useful, if not socially acceptable. J.B. Jefferys made the point explicitly: 'the spread of the hire-purchase method of trading helped to make the potential demand effective'. ${ }^{43}$ This is a crucial point, as it recognises that credit often (always) acts as an enabling connector between supply and demand. Consumers themselves acknowledged the benefits of credit. B.L. Coombes for example noted how credit not only helped furnish workers' homes but also helped to give a sense of pride to the

\footnotetext{
${ }^{40}$ Lancaster, The Department Store, 162.
}

${ }^{41}$ H. Shaw Sparrow, Hints on House Furnishing (London, 1909), 30. The American observer, Louise Boland More wrote in a similar vein in her book Wage Earners' Budgets of 1907, noting that the 'instalment system' was 'almost universal among the [American] working class for the purchase of pianos, sewing machines and parlour furniture, which is far out of keeping with the family income'. Quoted in C. Grier, Culture and Comfort (New York, 1988), 206.

${ }^{42}$ Shaw Sparrow, Hints on House Furnishing.

43 J.B. Jefferys, Retail Trading in Britain, 1850-1950 (Cambridge, 1954), 421. 
new owners. When he and his wife moved into two rented rooms in a south Wales mining village during World War One, he recalled: 'how proud I felt when I saw them furnished for the first time, and realised that all that shining new furniture was ours even if most of it still had to be paid for'. ${ }^{44}$

Retailers were aware that they could meet a wide range of demand by using credit as a sales tool. The Hackney Furnishing Company for example promoted its Equitable System of House Furnishing in a booklet that said 'if you are a poor man with only a few rooms you may have as much real comfort in your home ... as the nobleman in his ancestral halls'. They published a testimonial from one 'satisfied customer': 'I could easily pay you cash for this order, but what's the use? You give me no advantage if I pay cash, and why should I disturb my investments when your system enables me to pay out of income. If I could get lower price elsewhere by paying cash I would go elsewhere, but your prices are bottom. ${ }^{45}$

Debates over the provision of credit reflected contemporary changes in the market place. The technological developments of the late nineteenth and early twentieth centuries were such that new furniture was now affordable, albeit often on credit terms, to a larger and growing proportion of the population. ${ }^{46}$ In addition, there was a growing market for the renewal of furnishings in line with both changes in fashion and the effects of wear and tear. Stone and Rowe have shown that consumer expenditure on durable household goods (at constant 1938 prices) more than doubled between 1910-14 and 1935-8. ${ }^{47}$ In 1924, the Furnishing Trades Organiser reported that 'The amazing capital computed to be directly employed in [furniture] hirepurchase, amounting to not less than $£ 4$ million, upwards of two million hire-purchase

44 B.L. Coombs, These Poor Hand: Autobiography of a Miner (London, 1939), quoted in Benson, The Rise of Consumer Society, 77.

${ }^{45}$ Hackney Furnishing Company, British Homes: Their Making and Furnishing, 1911, quoted in P. Kirkham, R. Mace and J. Porter, Furnishing the World (London, 1987), 58.

${ }^{46}$ For changes in technology see C. Edwards, Twentieth Century Furniture Materials, Manufactures, Markets (Manchester, 1994), especially chapters 3 and 4.

47 R. Stone and D.A. Rowe, The Measurement of Consumer Expenditure and Behaviour in the United Kingdom, 1920-1938, vol. ii (Cambridge, 1966), Table 56, 35. 
agreements being signed annually. ${ }^{48}$ In 1921, it was estimated that there were 16 million agreements for all consumer durables, with 4 million new ones contracted each year. By 1935, this figure had risen to 24 million, with 7 million new agreements being signed annually. It was also estimated that at that time about 80 per cent of cars, 90 per cent of sewing machines, 75 per cent of furniture and 95 per cent of pianos, wireless sets and gramophones were bought on hire-purchase terms. ${ }^{49}$ Despite its popularity there were still voices raised against too much easy credit, and against hire purchase contracts in particular.

\section{Critics, and some supporters of the credit system}

Critical attitudes to retail credit were often based more on the prejudices of the observer than on the facts of the system. Paul Johnson points out that

Criticisms should have been not of the credit system itself, for this made expenditure on and consumption of services provided by a durable good more nearly synchronous than with cash payment, but against high rates of interest charged, lack of information for customers on the terms of credit, and the provision of shoddy goods which became totally worn out before instalment payments had finished. ${ }^{50}$

In fact, there were a number of supporters of the credit system. One economist, writing in 1927, considered that in the case of the purchase of durable goods, such as furniture, the total expenditure on the goods clearly preceded total consumption (i.e. until they fell apart), and the extended payment time was therefore completely justified. ${ }^{51}$ Some even went as far as to suggest that credit improved the moral fibre of the citizens of the country, in complete contrast to earlier critics who suggested that an 'over-stimulated demand in trade weakens the national character'. ${ }^{52}$

The banker, J. Gibson Jarvie, speaking at a conference of the Economic League in 1928, considered that hire purchase had a moderating influence on labour:

\footnotetext{
${ }^{48}$ Furniture Trades Organiser, December 1924, n.p.

49 P. Johnson, Saving and Spending: The Working Class Economy in Britain 18701939 (Oxford, 1985), 157.

${ }^{50}$ Ibid., 159.

${ }^{51}$ Ibid., 158.

${ }^{52}$ Shaw Sparrow, Hints on House Furnishing, 30.
} 
'psychologically, instalment selling has a value, for there is no gainsaying the fact that the moment a man has a stake in the country he becomes a better citizen’ ${ }^{53}$

However, certain dubious practices on the part of sections of the trade led to charges of poor quality goods, money-lending and even usury, rather than careful attention to the home-making needs of the nation. In 1919, Sir Leo Chiozza-Money, a left-wing economist, considered that ' the average furniture shop in poor districts is full of stuff only fit for a bonfire, and it is palmed off on the hire-purchase system at extravagant prices to poor people who have no chance of getting anything better. ${ }^{54}$

Issues around interest rates also caused much concern. In the wake of World War One, various cases were brought before local profiteering committees, ${ }^{55}$ where debates frequently hinged on the difference between cash prices, often with mark-ups of around 50 per cent, compared to hire-purchase sales that had a mark-up of 100 per cent. Retailers often successfully contended that these mark-ups were common throughout the trade, and had operated prior to the war. ${ }^{56}$ Apart from the financial criticisms, there were also serious scandals perpetrated by some retailers. Other dubious practices also provoked outcries: A court report from 1928 for example recorded how:

A working class woman bought $£ 6215$ s worth of furniture from a Tottenham firm on hire-purchase terms. Through illness, she got into arrears after $£ 532$ s had been paid ... In her absence the hire-purchase firm (Messrs Webb's of High Road Tottenham) caused her house to be stripped - save for an overlay and two pillows - and sought to recover removal charges of $£ 111$ s and offered their client an option to pay $£ 311$ s

\footnotetext{
${ }^{53}$ Quoted in M. Tebbutt, Making Ends Meet: Pawnbroking and Working Class Credit (Leicester, 1983), 170. Jarvie worked for United Dominions Trust and later campaigned vigorously against the 1938 legislation on hire purchase trading.

${ }^{54}$ Cabinet Maker, 25 January 1919.

55 Profiteering Committees were established under the Profiteering Act, 1919 and were organised under the aegis of local government councils. There were also committees set up for particular trades and suppliers.
${ }^{56}$ See examples of Jay’s Furnishing Stores and the West Central Furnishing Company quoted in Scott, 'The twilight world of interwar British hire-purchase', 198.


to collect the repossessed goods at her own expense and to pay 15 s a week until the debt was discharged, as a condition of re-letting them. ${ }^{57}$

Criticism also came from within the trade. In 1928 for instance, the chairman of the London retailer Shoolbred noted in the forward to Horace Vachell's book The Homely Art, that this publication (which condemned irresponsible credit) was 'an effort to combat the increasing temptations to buy fine phrases and free gifts instead of good furniture'. He further noted that 'every responsible furniture merchant will be grateful to Mr. Vachell for vigorously condemning the tendency to exploit furniture and the love of home, for money-lending purposes'.58

The furniture manufacturer Edward Pinto also commented on the usurious practices of many credit traders who 'did not work on a fair margin and then add something for hire-purchase; they worked on an exorbitant margin and then faked a very slightly lower cash retail price, to mislead the public into thinking how little they were paying for credit' ${ }^{59}$ These practices were highlighted in a debate broadcast by BBC Radio in 1937, focusing on the merits and demerits of hire-purchase. The manager of a cashbased department store quoted examples of mark-ups in the furniture trade. He instanced the case of a bedstead whose cost ex-factory was 21s, and was priced in a cash department store as 29s $6 \mathrm{~d}$, and in a hire-purchase shop at $41 \mathrm{~s} 6 \mathrm{~d}$, while the corresponding figures for a cane tub chair were (factory cost) 4s, (department store) 5s 9d, and (hire purchase store) 13s 6d. But the 'cream' he said 'is a bedroom suite, cost ex-factory 18 guineas, cash trade $£ 29$ 1s, hire purchase trade $£ 4519$ s’. 60

Retailers themselves were aware of the problems that might be caused by the indiscriminate granting of credit under difficult trading conditions. In 1933, the Cabinet Maker commented that 'owing to the increasing competition, the "spreadover” period has been extended in many cases to four years, initial deposits have been reduced and goods unsuitable for long term credit have been included’ ${ }^{61}$

\footnotetext{
${ }^{57}$ Quoted in A. Vallance, Hire Purchase (London, 1939), 62.

${ }^{58}$ H. Vachell, The Homely Art (London, 1928), Foreword.

${ }^{59}$ E. Pinto, The Craftsman in Wood (London, 1962), 134.

${ }^{60}$ Quoted in Vallance, Hire Purchase, 50.

${ }^{61}$ Cabinet Maker, 11 March 1933.
} 


\section{Retail practices}

Despite these problems, it seems clear that the provision of instalment credit had the effect of stimulating trade, enabling many households to furnish their homes and in many cases to purchase better-quality furniture than could have been afforded otherwise. Notwithstanding the obvious benefits to customers, retailers had to overcome the stigma of credit purchase, and went to some lengths to legitimise the process. For example, the London furnishing company, Drages Ltd, used a testimonial from the Countess of Oxford to praise the use of hire-purchase. She was apparently 'amazed to think that a man of moderate means can furnish for $£ 100.00$ on a payment of only $£ 2.00$, 62

The euphemisms 'furnishing out of income' or 'use as you buy' were no doubt intended to appeal to the sensibilities of [middle-class] consumers, but inevitably perhaps, much of the credit business was conducted with the working class. Indeed, Board of Trade estimates suggested that by the late 1930s, hire-purchase accounted for more than 70 per cent of sales of furniture to the working classes. ${ }^{63}$ However, there was still some moral opprobrium attached to instalment credit in the 1930s. A textbook on managing a hire-purchase business, published in 1930, stated that 'when a person furnished his house on credit he did so at the risk of endangering his social situation, and consequently had to proceed under the cloak of secrecy' ${ }^{64}$ The desire for secrecy was exploited by some retailers, either as a positive marketing tool by 'delivering in plain vans' to avoid connections with credit sellers, or negatively by threatening to publicise the names of payment defaulters.

The music-hall song below indicates a popular take on some of the themes associated with the provision of credit. The ridiculing observations on the lack of references, the incentives offered, and the 'delivery in a plain van' all reflected contemporary practices that encouraged business, but maintained secrecy.

'I've only just got married and I'm on the rocks and broke',

He said 'don’t let that worry you, why, money is a joke!

${ }^{62}$ Good Housekeeping, 1932, quoted in B. Braithwaite, N. Walsh and G. Davies, Ragtime to Wartime (London, 1986), 136.

${ }^{63}$ Scott, 'The twilight world of interwar British hire-purchase', 198.

${ }^{64}$ C.W. Aston, Hire-purchase Accounts and Finance (London, 1930), 3, quoted in Scott, 'The twilight world of interwar British hire-purchase', 198. 
Why, we only run our business to oblige you sort of folk, And we always lay your lino on the floor!'

'But Mr. Drage’ my Missus said ‘our neighbours know we’re new, And when they see your van, they're bound to say a thing or two.' He said 'they won't: we send it round in vans as plain as you. And we always lay your lino on the floor!'

So five hundred pounds in furniture, she spent did my Old Dutch;

'What deposit Mr Drage' said I 'would you require for such?'

He simply smiled and said 'would two and sixpence be too much? And we always lay your lino on the floor!'

I said 'That's very generous, but no reference I've got' He said 'we do not want; them they're a lot of Tommy-rot. Why you needn't even give your name, if you would rather not And we always lay your lino on the floor!'

‘Well thank you Mr Drage’ I said ‘you’ve really been most kind, But what about the payments?’ He said ‘that as you're inclined Pay half a crown a week, and if you can't well never mindFor we always lay your lino on the floor! 65 The lyrics also referred to the fact that it was the woman who selected the goods, but the credit agreement was in the husband's name. Although women were often seen as responsible for the home's decoration and functions, retailers were frequently reluctant to grant them credit, as the responsibility for married women's debts was unclear in law, and remained so until $1935 .{ }^{66}$

\footnotetext{
${ }^{65}$ N. Long, Drage's Way (c.1930), quoted in Lancaster, The Department Store, 100. ${ }^{66}$ The case of Jolly $v$. Rees (1864) had decided that husbands were not liable for their wives' debts if the goods purchased were not 'necessary' and the wife had been forbidden to pledge her husband's credit. The Married Women's Property Act of 1882 did little to improve the situation, and it was not until the Law Reform (Married Women and Tortfeasers Act) of 1935 that married women obtained full contractual
} 
The intense competition between retailers in this sector, and the way some businesses sought trade 'by advertising that they do not seek references, [or] that no deposit is required, and even that no payment need be made until thirty days have elapsed', ${ }^{67}$ caused consternation among critics and social reformers alike. The fear was expressed that 'it may lead to furnishing by improvident people, [thus] increase the bad debts on the part of the firms concerned, and consequent prejudice to the genuine buyer of furniture. 68

The biggest growth in furniture credit selling and particularly in hire-purchase was through the developing chains of multiple stores. Much of the success of the twentieth-century house furnishing multiples was based on their promotion and use of credit selling. J.B Jefferys made the point that: 'As the method of trading developed, the financial strength and financial ingenuity of the retailing firms became a more important factor in their success, than the quality of the goods sold or the particular techniques of buying and selling [they] employed. ${ }^{69}$ This financial strength enabled them to fund their own credit finance and make substantial profits not only on the merchandise, but also on the interest charged. The financial power of some firms also resulted in take-overs and amalgamations and the domination of the hire-purchase aspect of the multiple furniture trade by the Great Universal Stores group, which by the 1950s controlled hundreds of shops. ${ }^{70}$

Some firms did seem to become more interested in money lending than in selling furniture. The deposit and the weekly payment seemed to be more important than the

rights and liabilities. See also Finn, The Character of Credit, especially 264-72; E. Rappaport, “ “A Husband and his wife’s dresses”: consumer credit and the debtor family in England 1864-1910', in V. De Grazia with E. Furlough, eds., The Sex of Things: Gender and Consumption in Historical Perspective (Berkley and London, 1996), 163-87.

${ }^{67}$ Long, Drage's Way.

${ }^{68}$ H. L. Smith, The New Survey of London Life and Labour (London, 1931), 216.

69 Jeffreys, Retail Trading in Britain 1850-1950, 427.

${ }^{70}$ In 1950, the Great Universal Stores group controlled over half the total number of multiple furniture stores, including Jays and Campbell's, British and Colonial Furniture Co., Jackson’s and Smart Bros. Ibid., 425. 
goods. ${ }^{71}$ For example in the 1930s, the multiple branch business, Times Furnishing, had a slogan: ' $£ 1$ a month buys $£ 40$ worth of furniture', with no mention of deposit, interest rates or total payments. ${ }^{72}$ Furthermore, several dubious practices associated with credit selling increased people's low opinion of parts of the trade. Indeed, at various times during the century, legislation was introduced to curb practices such as the 'snatch back' of goods if payments were not kept up. However, legislation did not cover such activities as the substitution of goods seen by the customer in the showroom for inferior ones from a stock, and did not regulate interest rates. ${ }^{73}$

The financial problems faced by consumers who took on hire-purchase commitments to acquire furniture were often evident. These were the result of the mismatch between the demand for furnishings, especially in a new home, and the reality of finding the weekly payments, particularly in times of unstable employment. One example was cited by a social worker in 1936, after seeing that a furniture salesman on an unidentified 'large housing estate', had sold a customer 'a rexine three-piece suite, a Jacobean sideboard and a gate-legged table.' The consequences of the transaction soon became apparent when financial problems occurred. The social worker commented that:

[The customer soon] found they had surrounded themselves with debt, and first one thing and then another had to go. They found the attractive advertisements were just a myth, and instead of the shop-walker who showed them around and said 'won't you stay for lunch and let us send you home in a car?' they found on their doorstep one morning a very different type of man, and when he went their furniture went with him. ${ }^{74}$

There were some attempts to offer alternatives to these common commercial practices. The Co-operative societies initially had taken a moral position in regard to

\footnotetext{
${ }^{71}$ See the practices of the Crown Furnishing Company. National Art Library, Trade Catalogue Collection, Crown Furnishing Company estimate, 1892.

${ }^{72}$ C. Veasey, Good Furnishing Times Furnishing Co. c. 1935), National Art Library Trade Catalogue Collection

${ }^{73}$ For the 1938 Hire Purchase Act, see Vallance, Hire Purchase.

74 B.E. Astbury, 'The hire-purchase system: a social worker's views', Hire Traders' Record, April 1936, quoted in Scott, 'The twilight world of interwar British hirepurchase’, 198.
} 
credit provision. Rule 21 of the original Rochdale Pioneers charter stated that all goods bought and sold by the society should be paid for in cash. ${ }^{75}$ However, by 1911 79 per cent of societies were giving credit of some sort to their members. ${ }^{76}$ In 1923 , the attitude of the Co-operative movement was still that ' to trade with the tally man is the essence of improvidence, and the sooner the workers realize this the better it will be for them and the country at large. ${ }^{77}$ A training manual for furnishing staff noted that 'we know some societies that refuse to adopt the system (hire-purchase) owing to the disinclination of the committee or members to admit legalised credit'. ${ }^{78}$ Instead, they offered a club system that members paid into and then drew on when sufficient funds became available. By the end of 1929 outstanding consumer debts in Cooperative credit trading totalled over five million pounds, either in club trading or in hire-purchase. This was in part a response to the competition of multiple retailers, ${ }^{79}$ and in part a response to the economic realities of selling furniture.

Another alternative to commercial hire-purchase was a provision in the 1936 Housing Act, which authorised local authorities to supply new furniture to tenants on hirepurchase terms. This arrangement probably helped some buyers to avoid the more serious pitfalls of credit buying. For example, St. Helens allowed up to $£ 11.00$, Chesterfield $£ 12.00$ and Blackburn up to $£ 18.00$, although in this latter case the furniture remained the property of the Council. ${ }^{80}$ Prior to the Second World War, about 10 per cent of Scottish local authorities provided a quantity of moveable furniture, mostly under hire-purchase arrangements, although some supplied it free of charge 'chiefly in cases where the tenant's own furniture or bedding had to be destroyed because it was verminous. ${ }^{81}$

Thus, the first thirty years of the twentieth century saw great changes in the provision of credit and the subsequent expansion of consumption. However, injustices continued. As only the law of contract and common law were applied to hire-purchase

\footnotetext{
${ }^{75}$ Johnson, Saving and Spending, 131.

${ }^{76}$ Ibid., 136.

${ }^{77}$ Co-operative News, 3 March 1923, quoted in Tebbutt, Making Ends Meet, 169.

${ }^{78}$ A. Haigh, Furnishing and Hardware (Manchester, 1925), 189.

${ }^{79}$ Johnson, Saving and Spending, 137.

${ }^{80}$ D. Jeremiah, Architecture and Design for the Family (Manchester, 2000), 120.

${ }^{81}$ M. J. Elson, Housing and the Family (London, 1947), 105.
} 
agreements, the scope for redress through the courts was limited, and judgements were often harsh. In 1938, whilst hearing a hire-purchase case, Lord Justice McKinnon commented upon the nature of an unfair contract: 'If anyone is so foolish as to enter into such an agreement as this I do not know [that] his case can be considered harsh. ${ }^{82}$ Despite such remarks, changes in the law were made in the same year. The 1938 Hire-Purchase Act changed the nature of the law to specifically address issues and iniquities related to this system of credit selling. Notwithstanding the criticisms, some of which were undoubtedly well-founded, the development and rapid expansion of credit facilities in the period 1870-1940 was an essential component in the growth of the market for home furnishings. The 'never-never' had come of age.

\section{Post-war developments}

In 1948 Hermann Levy pointed out that 'instalment selling has become respectable' ${ }^{83}$ This may have been true in some quarters, particularly as the legislation of 1938 began to be implemented, but the evils of the trade were difficult to disperse, in the minds of critics at least. In 1946 the Board of Trade established working parties for a number of industries to report on post war needs. The Report on Furniture adopted a [deprecating attitude to hire-purchase, reaffirming that although abuses clearly existed, attitudes to credit were often based on prejudice of one sort or another.

As regards hire-purchase, we have been impressed by the unanimity with which manufacturers [my italics] have attributed to this section of the retail trade the main responsibility for many of the evils, which prevailed before the war. In particular, we have been told that it was the price pressure on manufacturers practised by some hire-purchase specialists which led to the competitive depreciation of quality. ${ }^{84}$

The Working Party Report also highlighted the less attractive aspects of credit retailing:

\footnotetext{
${ }^{82}$ South Bedfordshire Electrical Finance Ltd. v. Bryant (1938). This attitude contrasts directly with the old Christian doctrine of debtors being unfortunate and requiring charity.

${ }^{83}$ H. Levy, Shops of Britain: A Study of Retail Distribution (London, 1949), 149.

${ }^{84}$ Board of Trade, Working Party Report on the Furniture Trade (London, 1946), 145.
} 
The cost of hire-purchase facilities bears little relation to the value of the article: in fact it is probably true to say that the cheaper the goods, the heavier is the expense involved in the service because of the more frequent collection of the payments and the longer term of credit given in the case of people with small incomes. Although this aspect of the matter has sometimes led to unjustified complaints about the charges made by the hire-purchase firms, it has been an evil of the hire-purchase trade that some firms have tended to use the sale of furniture as a means of conducting a money-lending business and have been more interested in selling terms than furniture. There was also a good deal of public complaint before the war about the bullying methods adopted by some firms and the operation of the 'snatch back' (i.e. the recovery of furniture in cases where the consumer had difficulty in completing the payments). ${ }^{85}$

Complaints that hire-purchase retailers had unduly influenced the design of furniture were also aired in the trade's own press. In 1953, for example, the Furnishers' Encyclopaedia criticised 'hire-purchase interests, which had relentlessly forced down manufacturers' prices, [and then] advertised with sordid pomposity that the homes of the people were a true measure of national greatness'. ${ }^{86}$ However, the author conceded that hire-purchase had been a useful tool generally to help people on small incomes to reach a higher standard of living.

The success of credit facilities varied within the furniture trade. Many multiple businesses were running credit schemes that were highly profitable whilst also meeting market demand. They numbered their accounts in thousands, and often operated their own separate finance companies. However, for the smaller-scale retailer 'the offer of hire-purchase terms presupposes that he will carry the finance himself - a procedure which may embarrass him unless his capital is considerable or he can get the finance arranged through a specialist finance house' ${ }^{87}$ Whatever the internal arrangements for credit were, it is clear that they were very significant in the sale of durable goods. The Census of Distribution of 1950 showed that expressed as a

\footnotetext{
${ }^{85}$ Ibid.

${ }^{86}$ M. Sheridan, Furnishers’ Encyclopaedia (London, 1953), 212.

${ }^{87}$ Manchester Guardian Commercial, 1 July 1938, quoted in Levy, Shops of Britain,
} 149. 
percentage of all sales, 38 per cent of women's and men's wear; 80 per cent of radio and electrical goods, 80 per cent of furniture, and 100 per cent of sales in gas and electricity showrooms were on instalment terms. ${ }^{88}$ The Financial Times recognised this fact when in 1954 it suggested that 'It can now almost be said that in furniture retailing a good hire-purchase organization is as, or more important than, a wide range of designs. ${ }^{89}$

Nevertheless, the effects of hire-purchase were still of concern to critics on social, aesthetic and economic grounds. The National Council for Social Service in 1957 for example reported on the inability of households to balance budgets and the iniquities of high-pressure salesmanship, which continued to cause distress. In the same year, a commentator in Design magazine discussed the apparently iniquitous effects of hirepurchase, citing the example of a customer being sold a cocktail cabinet with an automatic light (although the house had no electricity), in which the customer then proceeded to keep bread. The writer thought this demonstrated just how far this method of selling could lead people astray. Finally, she said, 'the less informed, less intelligent section of the public turns to the shops which sell their wares the loudest and appear to offer the biggest bargains' ${ }^{90}$

The Design article continued with another reproach to the retailer, that of being a purveyor of bad design: 'For so long as most hire-purchase customers are docile enough to be misled whenever they enter a retail store, the general standard of furnishing is likely to suffer through the acceptance of poor and unsuitable designs. ${ }^{, 91}$ In the same year, the Christian Economic and Social Research Foundation suggested that the government provide credit facilities through Post Offices for young couples setting up home 'instead of occasioning those who supply the service to charge more for it.' 92

Not all commentators saw hire-purchase as an evil. In a report published in 1957, the Church of Scotland's Committee on Church and Nation for instance noted that 'Hire-

\footnotetext{
${ }^{88}$ J.D. Hughes and S. Pollard, 'Gross margins in retail distribution', Oxford Economic Papers, 9, 1957, 77.

${ }^{89}$ Financial Times, 31 December 1954.

${ }^{90}$ D. Meade, 'Furnishing by hire-purchase’, Design, 104, 1957, 41.

${ }^{91}$ Ibid.

${ }^{92}$ Kirkham, Mace and Porter, Furnishing the World, 58-60.
} 
purchase is often condemned as veiled money-lending, but it should be recognized that in many cases it is generally beneficial to society. Homes, holidays, motorcars and washing machines and [furniture] have been brought within the reach of almost all'. ${ }^{93}$

All these comments say as much about attitudes towards the working class and their consumption patterns as they do about credit issues, and in many cases, the retailer was portrayed as the villain of the piece, encouraging overspending or supplying inappropriate goods. The reality of retail practice was somewhat different. In 1956, J. G. Morrell wrote about his own experiences as a shopkeeper (with two shops) selling furniture to both middle and working-class customers. He discussed the fact that 'the bulk of [his] London business was with working-class customers and approximately 90 per cent of this was on credit terms. At his other shop, in a University town, the pattern of trade was more balanced, and only 50 per cent of the trade was on credit. He went on to say with regard to the London branch, that 'in common with most firms of this class of business, a hire-purchase charge was made of 20 per cent for 2 years' credit'.

Interestingly, he questioned why consumers seemed to stand for this. The reasons were not hard to find. 'I soon discovered that many working-class customers would not risk the possible embarrassment of making an appearance in the salubrious surroundings of a West End or middle-class store. This being so, they had to take their chance in their own kind of shops.' This was the case even though prices were apparently lower in the West End of London. 'I discovered that in the West End of London it was possible to buy comparable furniture on hire-purchase at a total cost slightly below the cash price charged by the [working-class] store to its customers. ${ }^{94}$ This retailer considered that working-class customers' anxiety was also tinted with apathy:

It is the deposit to be paid which becomes all-important and the knowledge that 'At such and such a shop I can have what I want on credit'. The existing hire-purchase customer is particularly prone to this influence. Opening the initial hire-purchase account is generally an

\footnotetext{
${ }^{93}$ Harris and Sheldon, Hire-purchase in a Free Society, 28.

${ }^{94}$ J.G. Morrell, 'Furniture for the masses', Journal of Industrial Economics, 1956, 27. My thanks to Judith Attfield for this reference.
} 
irritating sort of procedure. To continue at the same shop involves no further effort. ${ }^{95}$

[There is some truth in this, as customers tended to remain loyal to a particular shop or even salesperson. ${ }^{96}$

A revealing survey of furnishing problems on new housing estates in Manchester, undertaken in 1960, attempted to examine the effects of hire-purchase on family life. One respondent had a 'sparsely furnished home with nothing in the living room except two armchairs' but they said they would not take on hire-purchase because they were afraid of getting into debt. Conversely, another 'family admitted they had "to go into a lot of debt" over furniture and a neighbour said that their home was "like a palace” although she often "comes begging for a cup of tea”.' 97

In other situations, the benefits of hire-purchase were sometimes checked by circumstances beyond the influence of the trade or of its critics. In the 1950s and 1960s the government's use of credit controls as a [crude cut?] lever for the management of consumer spending particularly affected furniture purchases (Table 1). In 1964, an Economist report considered that consumer spending on furniture was prompted (or hindered) by the credit arrangements available:

The importance of credit trading, together with the fact that furniture purchases tend to be of a capital nature, have made this a trade vulnerable to government credit policy and to the general economic outlook. Perhaps the most important factor that triggers off the consumer purchasing decision is the amount of cash deposit, and the monthly repayments required on furniture. ${ }^{98}$

\section{Table 1}

Effect of economic measures on demand for furniture 1958-1968 ${ }^{99}$

September $1958 \quad$ Hire-purchase restrictions on furniture entirely removed.

${ }^{95}$ Ibid.

96 The author's own experience in the trade.

${ }^{97}$ Manchester and Salford Council of Social Service, Setting up House (Manchester, 1960), 16.

${ }^{98}$ Economist Intelligence Unit, Retail Business (London 1964), 18.

${ }^{99}$ M.R.V. Goodman, Review of the Domestic Furniture Industry (Stevenage, 1969). 
April 1960

January 1961

March 1963

February 1966

July 1966

November 1968
Hire-purchase restrictions re-imposed. Furniture 10 per cent deposit, 2 years to pay. Cars and domestic appliances 20 per cent, 2 years.

Hire-purchase restrictions eased. 3 years to pay on all these products.

Add-to facility on hire-purchase restored for furniture.

Hire-purchase restrictions tightened again - furniture up to 15 per cent deposit, 30 months repayments, as well as domestic appliances and cars.

Freeze and squeeze budget including further tightening of hirepurchase restrictions on all products. Furniture up to 20 per cent, with 24 months repayments. Purchase tax regulator increases furniture purchase tax to 11 per cent. Cars and domestic appliances from 25 per cent to 27.5 per cent.

Autumn budget to stem resurgent consumer spending. Hirepurchase restrictions tighten on all products on furniture 20 per cent deposit, 24 months to pay.

Table 2 partly reveals the impact of these government regulations on credit. The introduction of particular controls or their relaxation had a direct correlation with the trade of retail furnishers. The 1963 figure reflected the restoration of the 'add-on' facility, which allowed customers to add new purchases to an existing agreement, with usually only a small increase in weekly payments. In 1966 the double impact of two rises in the deposit requirements, as well as a rise in purchase-tax rates, resulted in a decline in the year's sales.

\section{Table 2}




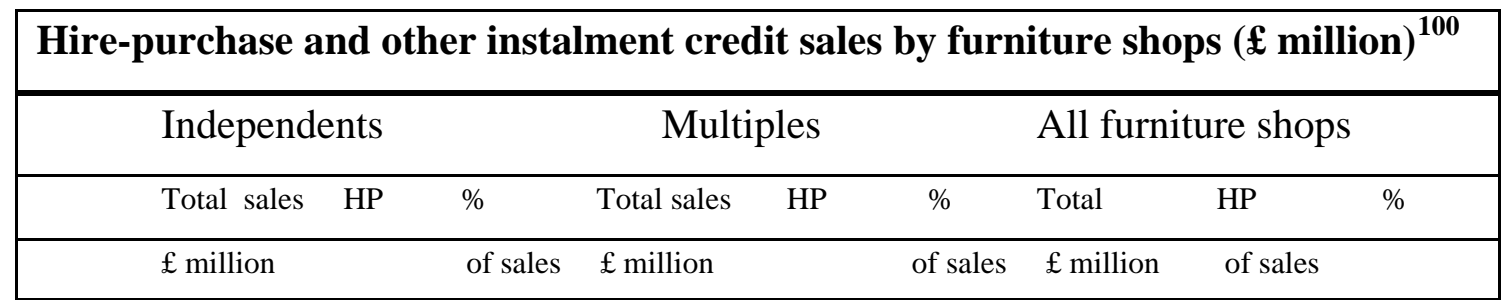

\begin{tabular}{|l|l|l|l|l|l|l|l|l|l|}
\hline $\mathbf{1 9 6 2}$ & 315 & 64 & 20.3 & 90 & 65 & 72.3 & 407 & 129 & 31.7 \\
\hline $\mathbf{1 9 6 3}$ & 315 & 63 & 20.0 & 96 & 67 & 69.8 & 411 & 131 & 31.9 \\
\hline $\mathbf{1 9 6 4}$ & 340 & 65 & 19.1 & 104 & 72 & 69.2 & 443 & 137 & 30.9 \\
\hline $\mathbf{1 9 6 5}$ & 358 & 70 & 19.5 & 111 & 68 & 61.3 & 467 & 140 & 29.92 \\
\hline $\mathbf{1 9 6 6}$ & 356 & 60 & 16.8 & 105 & 58 & 55.2 & 463 & 119 & 25.7 \\
\hline
\end{tabular}

Table 2 shows that even during a time of major government interference through credit controls, overall retail sales increased, although not surprisingly, hire-purchase business decreased as a percentage of the total. This is especially noticeable in the multiple sector, where hire-purchase was initially a significant part of their overall trade but fell from 72.3 per cent to 55.2 per cent of total sales over a four-year period. The restrictions imposed burdens on the retailer and encouraged them to side-step the rules and react to changes by developing new credit arrangements.

Since the 1970s, the proportion of hire-purchase trade financed by the stores has declined. The growing cost of financing the hire-purchase trade in-house has led many retailers to contract out their credit business. Other sources of finance have also increasingly become available to consumers, often in the form of a personal loan or credit card via a finance house. ${ }^{101}$ This factor often meant that consumers could become 'cash customers' in the shop and ask for and obtain discounts. ${ }^{102}$

In 1971 the Crowther Report on Consumer Credit was published. Many of its recommendations on changes to consumer credit law were later enshrined in the Consumer Credit Act of 1974. This afforded protection to people who entered into

${ }^{100}$ Economist Intelligence Unit, Retail Business, April 1967, 6.

${ }^{101}$ In a hire-purchase transaction, the title to the goods remains the property of the seller until they are paid for. In a credit sale, the ownership passes immediately to the buyer.

102 See Which? Magazine, October 1974, 307, for a report on furniture shops, where they recommended strategies for getting discounts. 
credit agreements in the following ways. Provided that the credit did not exceed $£ 25,000$, a customer could cancel a credit agreement within a certain period of time, as long as purchase was not made over the telephone, and they did not sign the agreement at the seller's shop or place of business. Secondly, creditors could not demand early payment, try to snatch the goods back, or end the agreement without having served a written notice to the customer, giving seven days' notice of their intention to take such action. Thirdly, if the customer had paid at least a third of the total price of the goods under a hire-purchase agreement, the creditor could not take the goods back without first obtaining a county court order. Fourthly, if the customer considered a credit agreement to be unfair, he / she could apply to the court and ask it [to consider the agreement and put in place a new agreement, or alter the old one However, the court would only do this if it could be shown that the agreement was 'extortionate'. Fifthly, as the creditor could either be the retailer or a third party source of finance, consumers could choose whom to sue if necessary. Finally, the Office of Fair Trading was required to licence any firm that undertook the business of credit supply. ${ }^{103}$

These changes offered more protection for the customer, so it was often the case that retailers resorted to offering a wider range of credit facilities, which in many cases were supplied by third parties. By the 1980s, financial market de-regulation, inflation and increasing prosperity amongst much of the population contributed to a heavier promotion of consumption and credit. One example from a specialist multiple retailer in the 1980s illustrates the choice available. In addition to cash or credit card payments, there was (a) a system of accepting three-monthly post dated cheques; (b) an 'Instant credit' agreement if a customer had a credit card available; (c) a standard hire-purchase or credit sale agreement; (d) a personal loan (via an outside provider), or (e) an arrangement with a lender such as the Provident, for a loan to be paid back weekly. It was also possible to pay into a lay-off account or savings account (with no interest paid) to accumulate a fund before spending it in-store. The choice of credit would ultimately be based on the rating of the customer.Other suppliers of furniture

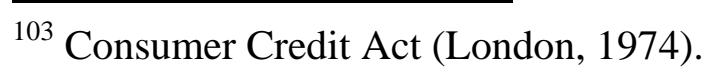


such as department stores offered rotating credit agreements, while mail order or club purchases were paid for by weekly payments through an agent. ${ }^{104}$

As recently as 1983, a Design Council report found that many people were still troubled by the morality of using credit to buy furniture:

Most people nurture some conception of the ideal home interior, but are prepared to let furniture give way to more immediate needs such as white goods or high-performance products like hi-fi or motor cars, and make do with what furniture they already have. For many households, paying for furniture can be difficult, as borrowing money for durables other than furniture is seen to be less self-indulgent. ${ }^{105}$

For three centuries and more, furniture retailers have sold their goods in ways appropriate to their markets. Even though there is an ever-growing interest in our homes and their furnishings, it is still often the case that many consumers and retailers seem to think that credit and the terms on which it is offered are the best way to buy and sell furniture. ${ }^{106}$

${ }^{104}$ R. Coopey and D. Porter, 'Agency mail order in Britain 1900-2000: spare time agents and their customers', in J. Benson and L. Ugolini, eds., A Nation of Shopkeepers (London, 2003), 226-48.

${ }^{105}$ Design Council Report to the Council on the Design of British Goods (London, 1983), 31.

${ }^{106}$ At the time of writing (2004), many retailers have been heavily promoting terms such as 'no deposit' and 'free' credit over three or four years. 